\title{
A Protestant perspective on Vatican II \& 50 years: An engagement with dissent
}

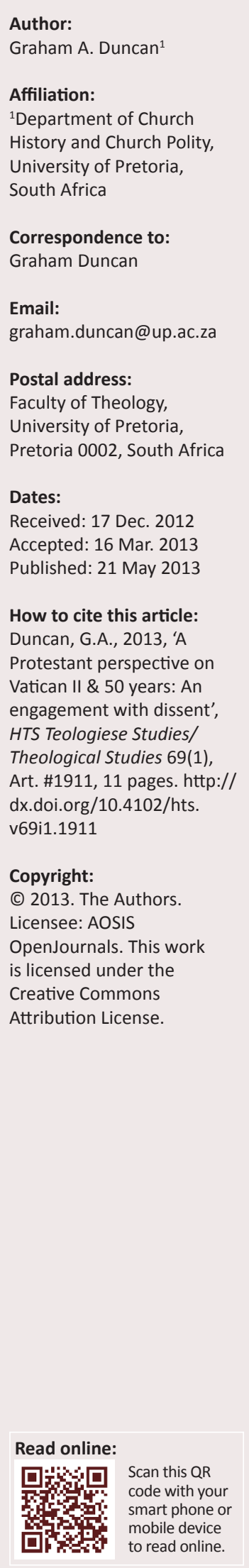

The Second Vatican Council (1962-1965) is regarded by many in Protestant circles as one of the most significant processes in ecumenical church history during the 20th century. At the time hopes were high that closer cooperation was a reality to be embraced and achieved. Concurrently, a younger generation of Roman Catholic theologians began to make their mark on the ecumenical theological scene. Their work has provided a bridge between the two ecclesiastical traditions, notwithstanding the subsequent negative response of the Roman church hierarchy. Despite important advances, recent pontificates have destroyed much of the enthusiasm and commitment to unity. This article examines the disjuncture in views regarding the outcomes of the Council and points of contact with Protestant thinking.

\section{Introduction}

On the 50th anniversary of the opening of the Second Vatican Council, an ecumenical council of the church, it is instructive to reflect on its results and subsequent developments in ecumenism. In the eyes of many Protestants and others, Vatican II has been placed alongside the World Missionary Conference (1910) as one of the most significant ecumenical event of the 20th century (Brandmüller 2005; Chadwick 1993:115-117; Edwards 1997:407; Gonzales 1975:239, 466; Hastings 1999:359; Lohse 1985:247; Marty 2007:133). However, a number of things have to be clarified before embarking on such a broad topic as encapsulated in the title. Firstly, the meaning of Protestantism is fluid and may be said to centre on the primacy of the doctrine of justification by faith (McNeill 1969:279), although historically, it has simply meant anti-Roman Catholic. Not all Protestants would accept the latter argument. The term Reforming is preferred as it conforms more closely to the semper reformanda principle of the Reformations, although it may be claimed to be similarly fluid. Both terms will be used in the course of this article. Secondly, there is no such thing as a Protestant response to the Second Vatican Council (Vatican II) for 'Protestantism' does not represent 'a homogeneous body of doctrine' (Pawley 1962:22). There may be as many views as there are Protestants, and this fact makes Protestants somewhat different from Roman Catholics (RCs). A Protestant magisterium has a different basis and control centre from the RCs. Thirdly, the meaning of 'Catholic' is equally fluid. I find it helpful to use Küng's (2008) understanding:

This is to be understood in two dimensions: being bound up with the church of all ages on the one hand and with the church of all nations and continents on the other. This is catholicity in time, interested in the continuity of the Christian faith, and catholicity in space, a universality of Christian faith embracing the different groups. (p. 166)

Küng (2008) expands this understanding into his own personal stance:

I want to be a catholic theologian in such continuity and universality of Christian faith. But couldn't a theologian calling himself Protestant or evangelical also be a catholic in this sense. Certainly ... (p. 166)

Fourthly, we constantly have to attend to the 'bitterness of history' - 'propaganda and prejudice' (Pawley 1962:23). I was a minister in the west of Scotland for 10 years and witnessed the bitterness of historical memory turned to prejudice on both sides of the faith divide. I took a mischievous delight in reminding my Presbyterian congregation that the church we loved and worshipped in had been a RC chapel for longer than it had been a Reformed church. Fifthly, the concept of Reformation has to be interrogated - whose reformation, when and how? For instance, it was Pope Innocent III who, at the Fourth Lateran Council (1215), used the term: propter reformationem universalis Ecclesia [a reformation of the universal church]. History demonstrated that we have many differences in our conceptions of the Church, particularly with regard to teaching office and authority. Yet, we acknowledge the same root which is a visible body that has authority in matters of faith. Different branches have sprung from this root, with the Roman Catholic Church having a certain invariable hierarchical structure, infallible and a source of authority, namely the Bishop of Rome as the successor to Peter's office (Pawley 1962:34). Yet, considering the New Testament witness and those of the early church fathers, we might all agree that:

... what was clearly intended from the beginning was a conciliar type of authority, properly constituted, and founded on a full consensus, through which, not by infallible revelations, but by general and steady 
guidance, the Church's divine founder could send the Holy Ghost to lead the church progressively into all truth. (Pawley 1962:35)

Sixthly, we should not delude ourselves: The church has hardly ever been united. We have never been able truly to sing (Revised Church Hymnary [Baring-Gould] 1927):

We are not divided,

All one body we,

One in hope and doctrine,

One in charity. (p. 655)

The best that can be said is that 'most of Christendom had managed to preserve its unity for a thousand years' (Pawley 1962:24). The tragedy of both history and our current situation is:

that two bodies who agree ... as to the manner and nature of our Lord's incarnation should be separated by a disagreement about the nature of his presence on the Eucharist. Or that, agreeing that His own sacrifice upon the cross is an atonement for the sins of mankind, they should disagree over the way in which that sacrifice is made effective for man's salvation, or the way in which the Eucharist itself can be called a sacrifice. (Pawley 1962:33)

A question arises inevitably: If the church is not one, holy, catholic and apostolic, can we still say that it is the church? If indeed these are the essential marks or dimensions of the church, this question is relevant to the ecumenical discussion.

Finally, there is another issue that is intriguing and presents a line of less resistance in offering a critique of recent $\mathrm{RC}$ historiography. It comes from the previous Archbishop of Canterbury:

I've heard it said that one of the greatest triumphs of Catholic Christianity is its ability to train its own critics. And this means surely that Catholic tradition ought to be concerned with presenting a depth and range of resources that will stop anyone from too easily believing that the Church at any one moment has got it all wrapped up, has fathomed the meaning of Jesus Christ. (Rowan Williams, address at the inauguration of Affirming Catholicism [1990] in Higton 2004:35-36)

The issue is put somewhat differently by Küng (1986:62) who correctly asks, 'I wonder whether Protestants will now take up the protest themselves again, instead of leaving it to critical Catholics.' Related to this, Dr Christof Blocher, President of the Swiss people's Party of the Canton of Zurich, National Councillor and Protestant stated on 08 January 1980: 'The controversies of the Catholic Church are far more important than the current attempts at improvement in the Protestant Church' (Küng 2008:481) for from a different focus '... the 1960s Catholic debates and reforms associated with Vatican II are ... the best known manifestation of longstanding liberal-conservative divisions amongst Protestants, Catholics and Jews' (Chaves 2011:82). However, all of this has an 'ecumenical' history.

\section{An ecumenical council (Vatican I)}

Vatican I was the first general council held since the Council of Trent (1545-1563) 'as a function of the programme against the Reformation and not of reconciliation and reunion' (Küng 2001:146). It was at best an incomplete council. On 20 September 1870, the Kingdom of Italy captured Rome and annexed it. One month later, on 20 October, Pope Pius IX suspended the Council indefinitely. It was never reconvened and formally closed in 1960 prior to the Second Vatican Council. Regarding its most famous output, Pawley (1962) claims:

... it was intended that the doctrine of infallibility should be seen as part of a whole body of doctrine concerning the magisterium ecclesiae (authority of the Church), and that the doctrine should be related very carefully to the rights and functions of the provincial bishops, or of a council lawfully convened. (p. 58)

Yet, this did not happen despite a last minute intervention before the promulgation of the document Pastor Aeternas through an attempt to insert 'even one phrase mentioning the role of the episcopate in formulating an important statement of the faith' (Costigan 2005:1). Wilde (2007) argues as follows:

However, without any corresponding decree about the importance of the college of bishops, the curia focussed on the primacy of the Pope and his infallibility in the century between Vatican I and Vatican II. (p. 60)

This unresolved heritage persists to the present time (Küng 1971a:163) although another council was more recently convoked.

\section{Another ecumenical council (Vatican II)}

In his speech at the opening of Vatican II on 11 October 1962, Pope John XXIII stated, according to Abbott (1966):

... 'Ecumenical Council'. We [first] uttered those words in the presence of the Sacred College of Cardinals on that memorable January 25 1959, the feast of the Conversion of St Paul, in the basilica dedicated to him. (pp. 711-712)

He went on to outline the purpose of the council: 'Principle [sic] duty of the Council. The defence and advancement of truth. ... How to repress errors. ...' (Abbot 1966:713-719).

The unity of the Christian and human family must be promoted (Abbott 1966:713-719.) Whilst these laudable aims might appear to be somewhat contradictory, it led to the establishment of a Secretariat for Promoting Christian Unity in 1960. The fact that, from the outset, the council was introduced as having some bearing on the question 'of the unity of Christians caused considerable rejoicing in circles far outside the Roman Church' (Pawley 1962:59).

In Ad Petri Cathedram, Pope John referred to:

a vision which those who are separated from this apostolic see may regard as a gentle invitation to seek and to follow that unity which Jesus Christ implored from His Heavenly Father with such fervent prayers. (Pawley 1962:64)

This meant that ' $[t]$ he Church was to be renewed in such a way as to make reunion more possible for those separated from it' (in Pawley 1962:64; cf. Cornwell 2004:39; O'Connor 2005:156). Yet, this was still reunion within the Roman 
Church as was made clear in a speech to a commission on 30 June 1959:

... when we invite you into the unity of the Church, we are inviting you not to the home of a stranger, but to your own, your Father's house. It belongs to you all. (Pawley 1962:66)

Unitatis Redintegratio (\$6) refers to 'that continual reformation of which she always has need' (Abbott 1966:350). Pope John Paul II, in an address to the Catholic University of America, Washington, on 07 October 1979, said:

The church needs her theologians, particularly in this time and age ... The Bishops of the Church ... all need your theological work, your dedication and the fruits of your reflection. (Hebblethwaite 1980:25)

According to Küng (1986), a starting point for understanding Vatican II is that the:

Roman church bureaucracy ... never did want and never did like the Second Vatican Council, ... [and] never ceased lamenting the loss of the medieval-counterreformation -antimodernist image of the pope which had prevailed in the preconciliar era, hoping to reinstate it as speedily as possible. (p. 1)

Two vital issues have to be grappled with: What has happened in the Roman Catholic Church with regard to reform? What is the RC's response to reform and to the Protestant world?

Vatican II set in motion both a backward and a forward movement. Küng was one of the most able exponents of the forward thrust. Conway (2010) makes the following point:

... the Roman Catholic Church had held its Second Vatican Council, revealing itself as a much more open and collaborative church than it had earlier seemed to be, even if later papal decisions have sometimes seemed to hark back to earlier models. (p. 23)

The quality of 'seeming to be' defines the problem with interpreting Vatican II, for at times, we are caught at the interface between appearance and reality. However, argues Küng (2008), here was a church in motion:

... the reformers at the Council, and I in particular, did not simply stand still at Vatican II but continued to move forward. We were led to that by the Council with its compromises, half measures and ambiguities. (p. 134)

Küng (2008) affirms that this led to the publication of many of his subsequent works:

I change in response to the impulses of the Second Vatican Council ... and I am also provoked by the contrary experiences that the Catholic church community has with the post-conciliar Roman Curia. (pp. 134-135)

Catholic theology enjoyed something of a revival during and immediately following Vatican II. The names of Congar, Rahner, Schillebeeckx and Küng were as honoured at Vatican II as were those of Montini, Suenens, Frings and Alfrink: 'Cooperation between the hierarchical magisterium and theologians had rarely been closer or more productive' (McBrien 1986:295). They also became established interlocutors amongst Reforming thinkers. By 1986 , however, ' $[t]$ he Vatican ... is rooted in an ecclesiological perspective which continues to define the church primarily, if not exclusively, in hierarchical terms' (McBrien
1986:298-299). These were 'hopeful times', signalling 'the renewal and opening up of the Catholic Church to the wider Christian and secular world'. Küng (2010) claims:

At that time, the Catholic Church had reached a high degree of credibility with the Second Vatican Council (1962-1965) ... But how sorry things became in the post-conciliar restoration that soon set in, which brought with it a fatal decline in the credibility of the church. (p. 39)

For Reforming academics, Küng (2010) was to become an iconic figure:

So from beginning to end I put my trust in God's grace. But isn't that quintessentially Protestant? I think that it is quintessentially evangelical, i.e., in keeping with the gospel. ... Moreover, all that is quintessentially evangelical, it is also quintessentially catholic. (p. 162)

Küng demonstrated a rather broader theological perspective than was traditionally accepted. He reinforced this view in On being a Christian and concluded his work by discussing the topic of his early research, namely the central theme of the Reformation, the justification of human beings before God (or social justice?). This culminates in the epilogue on a summary of what it entails to be human. Being human is exemplified in being a Christian, which is understood as radical humanism that can integrate and overcome even suffering, guilt, death and meaninglessness. At the end, I summarise the whole book in a single sentence, which will remain my motto for life:

By following Jesus Christ man in the world of today can truly humanly live, act, suffer and die: in happiness and unhappiness, life and death, sustained by God and helpful to men. (Küng 2008:307; cf. 1978:602)

Much as Küng wanted and supported change in the church, he viewed the ecclesia semper reformanda principle in the same light as Busch (2010:55), that is: 'The church is the church of Jesus Christ only to the extent that it lives in constant repentance.' Küng (2008) clearly stated:

While I resolutely support reforms, I am equally resolutely against any split in the church. We must above all avoid the mistakes of modern Protestantism - sectarian encapsulation, mutual excommunication and the constant splitting off of churches. ... Being Christians together is more important that being traditional or progressive. (p. 320)

However, there was also evidence of a backward thrust in the Roman Catholic Church, and Küng (2008) was soon to become sadly disillusioned:

A year of his [John Paul II's] pontificate is enough to show very clearly the direction in which the ship of the church is to be steered: evidently not accepting the impulses of the [Vatican II] Council but backwards. As far as this is still possible, this is a restoration of the status quo before the council. (p. 431)

By the end of 1979, Küng (2008) wrote:

John XXIII and the Second Vatican Council are forgotten. ... Human rights and Christian love are preached outside the church, but within it despite many fair words they are scorned ... (p. 474)

So the concept of the church became the locus of conflict at the Council. 


\section{The church}

Whilst the Council of Trent focussed on the institutional nature of the church, Vatican II concentrated on the people of God image based on equality though baptism. The concept of the church of Christ subsisting in the Roman Catholic Church was held in tension with other churches and faiths sharing in varying levels in Christ's truth as the result of his grace. 'If the perspective of the Council of Trent (1545-1563) had been the church as an institution, ... Vatican II's was of the church as the people of God, a community of equals by virtue of Baptism' (Bevans 2010:7; Lennan 2010:239); '... while Christ's church 'subsists in the Catholic Church', both other Christian bodies and peoples of other faiths participate in various degrees in Christ's truth through his grace' (Bevans 2010:7; cf. Lumen Gentium [LG]\$8 in Abbott 1966:23; Dulles 1971:118). The concept of the church as an organism in opposition to an organisation can be traced back to the encyclical Mystici Corporis of Pius XII: 'And one could show more generally that the Council adopted and extended to the whole Church the best thinking of parts of the Church' (Hebblethwaite 1975:11), even with regard to ecumenism. The aim of the Council was in relation to liturgy to '... make more responsive to the requirements of our times. ... to nurture whatever can contribute to the unity of all who believe in Christ' (Sacrosanctum concilium $\$ 1$ [Abbott 1966:137]). This was apparently true with regard to the church's innovative attitude to the world which included other Christian denominations and faiths as is reflected in Gaudium et spes which emphasised a novel commitment to the world based on an increasing sense of unity. However, this view has been challenged by Schloesser (2006:281-285) who perceived a greater degree of fragmentation in global affairs at the close of the colonial era. Schloesser (2006:295) suggests that atheistic and existentialist philosophies influenced the thinking of Nostra Aetate on the subject of religion (cf. \$1, in Abbott 1966:660-668): 'What, finally, is the unutterable mystery which engulfs our being, and whence we take our rise, and whither our journey leads us?' This is a challenge for mutual understanding.

Lumen Gentium (LG, Dogmatic Constitution of the Church) was characterised by biblical metaphors and historically contextualised language. It 'presented a more fluid model of Christian community's identity in history' (Massa 2010:8). Küng (2003:349) refers to this as the 'communio model of the church oriented on the Bible' compared with the 'absolutist pyramidal model'; LG§1 is inclusive of the many images of God's community in biblical and patristic sources, while LG§2 emphasises in particular the image of the people of God in history. Notwithstanding this, this mage was to be sidelined in favour of an organisation more strictly controlled by Pope and curia than ever. LG§1:

insists on the irreducible diversity of biblical and patristic images of the mystery of God's gathering of humankind, the mystery of the Church; LG\$2 nevertheless privileges one such image: that of God's 'people' on the move through history... [Unfortunately], ... only 37 years after the promulgation of $L G$, the Church would be far more rigorously and monolithically controlled by Pope and curia than at any time in its history. (Lash 2003:16, 17)
John Paul II claimed that 'the way to interpret Vatican II is not with its vision of the future but its ties to the past' (Modras 1986:48). For him, somehow the outcomes of Vatican II have to align with those of Vatican I in order to maintain continuity with the magisterium. This became 'the' hermeneutical issue of a post Vatican II between the reformers and the conservatives (see below 'The real untold story'. John Paul II focussed on the hierarchical structure of the church rather than its being the people of God (LG§10). He eschewed and possibility of lay leadership in any significant sense despite assertions to the contrary in LG\$31 where the laity are accorded priestly, royal and prophetic functions:

Wojtyla's idea of the laity clearly precludes anything like lay leadership in the church. His conception of the priesthood and religious life hardly leaves room for social and civic involvement let alone political activity. (Modras 1986:49)

Yet, in $L G \S 31$, it is stated:

They are in their own way made sharers in the priestly, prophetic and kingly functions of Christ. They carry out their own part in the mission of the whole Christian people with respect to the Church and the world.

There is no room here for a ministry of all believers.

Yet, $L G$ defined the Church as a pilgrim people, the people of God in transit. It was no longer a static perfect society (Massa 2010:8). Massa (2010:9ff.) refers to the Vatican's 'dirty little secret' as the 'new historical consciousness unleashed by Vatican II' (Massa 2010:9):

that the Church had changed its preferred metaphor for thinking about itself over the course of its history. ... This field of tension demonstrated the disconcerting truth that Catholicism wasn't simply a single stream, but multiple streams mingling in a deep and wide tradition. The very pluralism of the models bore powerful witness to the fact that manyness and tension were as intrinsic to the community of the faithful as were uniformity and docility. (Massa 2010:44; cf. Lonergan 1967:129; Schloesser 2006:307-308)

Massa (2010:10) posed a pregnant question: 'What if the institutional structures of the Church were not of divine origin, but were subject to perpetual evolution?' (cf. Schloesser 2006:306-307). This is represented in Lonergan's (1967:127) modern paradigm over against the classicist paradigm. 'Christian theology was put in an impossible position when the best of modern thought was perceived as an impossible challenge' to divine revelation (Massa 2010:13) since ' $[t]$ he council jettisoned the historically isolated idea that the Church was outside time and history' (Ivereigh 2003a:1). This replaced 'the pyramidal structure with a iterative and helical conception' ('a people's church hierarchically structured') (Ivereigh 2003:2).

It was clear that many things have changed in the classicist paradigm:

- attitudes to authority, sex, worship, other Christians, other religions. But perhaps the most fundamental change is one that the majority of Catholics themselves are scarcely conscious of. 
It's the fading away of the traditional Catholic metaphysic - that marvellously complex and ingenious synthesis of theology and cosmology and casuistry, which situated individual souls on a kind of spiritual Snakes and Ladders board, motivated them with equal doses of hope and fear, and promised them, if they persevered in the game, an eternal reward. (David Lodge 1980, How far can you go?, in Duffy 2003:51).

Lodge's view of the church is that of a manipulative, inflexible system created for the benefit of some abstruse controlling power. For Duffy (2003):

Apparently timeless certainties had actually turned out to be part of a package, wound into and in part dependent for credibility on a set of cultural practices and attitudes which have now gone or are going as irrevocably as the demise of dinosaurs.

... But it was a way of life which, though it seemed immemorial, was actually a cultural construct, the product of a network of circumstances. (p. 52)

When, not very surprisingly, 'a heavily clerical and authoritarian institution failed to transform itself at once into a place of dialogue and partnership between laity and priesthood, sharp disillusion set in' (Duffy 2003:54). Here the reference is to 'the characteristic values and institutions of democracy - dialogue, consultation, accountability' (Duffy 2003:54). Duffy (2003) understands the dynamic of a committed community where:

... in a family, you cannot maintain unity, love and shared purpose by kicking people into line. A common mind and heart come from the shared exploration of a common inheritance, and the shared pursuit of a common hope. Tradition is not orders from above, or the status quo, a code of law, or a body of dogma. It is a wisdom, embodied in a complex tissue of words, symbols, law, teaching, prayer and action, a way of life which has to be practised before it yields its light. (p. 64)

Duffy is reacting negatively against the 19th century societas perfecta image of the church which was foreign even in the Medieval period where the church was a complete society with all the means a society needed to pursue its own aims' (Weakland 2003:79) to keep the church independent of temporal power: '... the church possessed the authority structures needed to function adequately and enforce its decrees' (Weakland 2003:80). This is reflected in a number of contested timeless issues which have their origin in particular circumstances which appear obsolete today. These include surviving the worldly pressure to conform to its norms through outright opposition to then, a centralised bureaucracy, centralised appointments, enforced celibacy all of which are strongly contested in secular circles. For example, celibacy arose historically out of the Gregorian Reform in the 11th century where the church was resisting enforced subjugation, seeking to maintain its freedom as a countercultural institution (Radcliffe 2003:124-125). However, these conditions no longer apply and as a result of being tied to tradition, however anachronistic and inexplicable, and its self definition as a 'perfect society. The operations of the curia remain shrouded in mystery and even the Vatican's financial status has only recently been partially revealed (Woodrow 2003:220) by the crude exercise of its authority.

\section{The problem of authority is the problem of the challenge to authority}

At the beginning of Vatican II (13 October 1962), it was noted that Catholic tradition enshrined in Codex Iuris Canonici, canon 228\$1, states 'Concilium oecumenicum suprema pollet in universam ecclesiam potestate': the ecumenical council has ultimate authority over the whole church (quoted in Küng 2003:278). Yet, the subsequent emphasis relating to authority has been on:

... the two papal dogmas of Vatican I (the primacy and infallibility of the Pope) [which] have deepened the schism with the Reformed and Orthodox churches. ... On the basis of the records I have to demonstrate that neither Vatican II nor Vatican I, to which it refers, cited scriptural proof or a universal ecumenical testimony of tradition for this thesis. (Küng 2008:152)

The issue of authority was triggered by rejection of the official report on birth control. Humanae Vitae (HV) in 1968 after the council had closed. This resulted in serious debates regarding ecclesial authority amongst Catholic theologians (Massa 2010:48) and lay people. A number of things had changed apart from the times, such as attitudes towards authority. Lay people were far less likely to give unquestioning obedience to decisions that ran contrary to their inner voices and common sense. The rise of historical consciousness (pluralism) demonstrated that 'the older static and classical concepts and arguments from neoscholastic natural law could no longer provide a believable substructure for Catholic moral teaching' (Massa 2010:48). The problem was that underlying $H V$ was an assumption 'that the church is identical with the hierarchical office' (Mayflower Statement 1968:\$3 \& 4). With regard to the teaching office, Dulles (1971:96-97) argued that for centuries it was not only bishops who were entrusted with the teaching office. Catholic theology for many centuries, from the early church until the Renaissance period was devoid of a monolithic form of institutionalism. Pluralism was the 'most Catholic stance of all' (Massa 2010:146). Massa (2010:159) emphasised that an ahistorical approach to church teaching and practice is no longer tenable by defending seemingly eternal propositions. The fact is that change occurs, and it is no longer possible to defend the contrary position. Cardinal Ratzinger (later Pope Benedict XVI) found the source of all evil. ... in a modern world that has invaded the church' (Küng 1986:61) whilst Dulles 'recognised that pluralism was, in itself, a profoundly Catholic value, and he found that pluralism in the history of the Catholic tradition itself' (Massa 2010:161).

\section{According to Woodrow (2003):}

The problem ... is that while Vatican II presented a new daring vision of the church as 'People of God', thus standing the hierarchical pyramid of the old power structure on its head, it failed to provide the means to turn this vision into reality or transform the institution. ... Throughout history, authoritarian and liberal popes have succeeded each other. And the excesses unleashed by the Council (priests and religious abandoning their ministry, Marxism being preached under the guise of 'liberation theology', Catholics adopting a 'self-service attitude 
to the Church's teaching) were bound to provoke a backlash in Rome. But the election of a pope [John Paul II] both charismatic and authoritarian, socially progressive and theologically conservative, popular and intellectually powerful, has singularly compounded the problem. (p. 215)

In the long term this has led to the situation where it can be said that the contemporary problem is that of authority which is presented in the form of an authoritarianism, which operates by means of ridicule, humiliation and alienation which is divorced from 'healthy authority' (Kennedy 1986:300). Here is a problem that has outlived its usefulness for the world has changed irrevocably for:

It no longer provides a credible reflection of historical, physical, or spiritual experience. ... The authoritarian defences of religious metaphors as literal truth kill their inner spiritual meaning. Authoritarian leaders are, however, comfortable with unambiguous concrete faith, and ill at ease with mystery, the central identifying component of all true religion and all true human experience. That is why such leaders possess so little true spiritual authority, that is, authority that naturally attracts the attention of searching believers. (Kennedy 1986:302-303)

Greeley's (1986:287) advice to church hierarchy is apposite in this context: '... they should stop deceiving themselves that reality is different.' This is problematic in a community that is essentially world-denying as exemplified by pope Benedict XVI.

Vatican II caused 'an explosion of hope' (Tracy 1986:268) that was universal. Further, according to Tracy (1986:271) 'what should have been an intellectual argument became an institutional coercion - and with a price to intellectual integrity that we are still paying'. This can be compared with:

Protestant neoorthodox theology ... was ... free, open, argumentative. It was a theological argument - an exercise in persuasion, not coercion. ... Theology - which is, after all, a major part of any vibrant religious tradition - can best perform its services when the mystical and institutional elements are also strong. (Tracy 1986:271)

In broader context in terms of being a world church this 'can certainly not be sustained by structures of control from a single Roman centre aided and abetted by movements of (for the most part) parochially Mediterranean origin and character' (Lash 2003:28). This is linked to the traditional role of the See of Peter whose vocation is 'to facilitate and enable, not to control and dominate through power over all appointments and the issuing of endless streams of "orders" and "instructions"' (Lash 2003:25). Needless to say, all of this required a new legislative framework.

\section{New Code of Canon Law}

The new Code of Canon Law clearly encourages and even requires lay involvement in the affairs of the church for:

The Christian faithful ... have the right and even at times a duty to manifest to the sacred pastors their opinion on matters which pertain to the good of the Church. ... Those who are engaged in the sacred disciplines enjoy a lawful freedom of inquiry and of prudently expressing their opinions on matters in which they have expertise. (Canons 212, 3; 218, in Swidler 1986:306)
This requirement extends also to theologians. Yet, it seems to be quite out of touch with the post Vatican II spirit for such thinking reflects the ethos of Vatican II:

Through recognition of the 'signs of the times', 'Christ summons the Church, as she goes on her pilgrim way, to that continual reformation of which she always has need. ... Let everyone in the church ... preserve a proper freedom ... even in the theological elaborations of revealed truth. ... All are led ... wherever necessary to undertake with vigor [sic] the task of renewal and reform. (Decree on Ecumenism, Unitatis redintegratio, $\$ 4$ in Abbott 1966:347)

The emphasis here is on lay participation in the life and witness of the church and that this should be integral to a process of constant reformation and suggests a greater commitment to collegiality at all levels of the church, not least amongst the episcopate.

\section{Collegiality}

\section{At Vatican II:}

Progressives believed in the doctrine of 'collegiality', which, in essence, stated that the bishops, when convened as a council, are as infallible as the pope - a doctrine that conservatives saw as threatening his authority and primacy. (Wilde 2007:57)

The emphasis on collegiality has to be seen in a far wider perspective than world tours demonstrating solidarity (if that is what it was?) with local bishops and celebrating the sacrament with them (cf. Novak 2003:35-36), ' $[t]$ o be Catholic means to be in communion with Rome' (Novak 2003:38). However, events subsequent to Vatican II have demonstrated a form of collegiality that is totally dependent on the whim of the pope. This needs to be reformed to develop authentic collaboration through participation in a decentralised system (Küng 1986:14-15) which should include the laity and women in particular. However, the reins of power are entrenched in the papacy.

\section{The Papacy}

The enduring issue is that neither the vision of Vatican II, nor that of Vatican I was seen through to its logical conclusion. Of course, it was not in the interests of the Curia to have to deal with a reformed and reforming pope who constantly referred issues to the universal episcopate. For whatever reason it did not tackle the sensitive matter papal supremacy:

The present imbalance in Church authority is not only between pope and bishops but between the three 'voices of the Church' ... that of government (tradition), that of theology (reason) and that of pastoral experience (the laity)'. [There is] a verbal inflation of the first voice, that of the Curia, which has assumed an usurped authority. The second voice, that of the theologians, is too often stifled, whereas they should be allowed freedom of research and doctrinal pluralism. As for the third voice, that of the laity, they have no recognised forum in which to express their opinions. The promises of Vatican II have not been fulfilled. (Cadrin cited in Woodrow 2003:216)

The only form of collegiality which existed appears to have been between the pope and the Curia. They together, at least, appeared and still appear to be of one mind. But further, the 
theologians and the laity were in great need of liberation for service. The situation had changed considerably for many reforming thinkers regarding authority in the church. In a very real sense, Küng, who is at one with the Protestant theologians Moltmann and Pannenberg, stated that he saw:

an increasing consensus also amongst Protestants on the need for an office of unity, as a sign and instrument for remaining in the truth that is promised to the church. (Küng 2008:429)

I remain true to my conviction that a Petrine office (papacy) oriented on the constitution of the New Testament church and the great Catholic tradition of the first millennium with a moral and pastoral rather than a formal juristic authority can still be an opportunity for Christianity as a whole. ... I also get interesting support for a pastoral primacy in the service of Christian ecumenism. I also get increasing support from the Protestant side. (Küng 2008:428)

Küng (1971a) had already given this matter serious attention in terms of 'a primacy of service':

Thus the Pope could take a new view of his function in presentday Church and society. Together with the bishops, he would provide a new form of service to the community of the Church and its unity ... . He would be an inspirer in the spirit of the gospel and a leader in the post-conciliar renewal, and Rome would become a place of meeting, dialogue and honourable and friendly co-operation. (p. 202)

This is a vision many Protestants could and would identify with and, referring to The Church (Küng 1971b), Küng declared 'on this basis a reconciliation between Rome and Canterbury would one day be possible - a model for further progress in the Christian ecumene' (Küng 2003:452). Things had certainly altered considerably within ecumenically minded Catholics and Protestants and had begun to take account of its perspectives.

\section{Realising Protestant concerns}

One of the greatest gifts to the Protestant world was the reform of the liturgy in Sacrosanctum concilium. This was the fruit of the Liturgical Movement and brought about the optimum level of common ground in worship. In addition, ' $[t]$ he proclamation of the word of God is again heard in a comprehensible way. There is active worship by the whole priestly people' (Küng 2003:292). Great co-operation was secured in the field of liturgy through the ecumenical International Consultation on English Language (ICEL), particularly with regard to the liturgical texts and a revised lectionary. However, in 2000, a new edition of the Roman Missal was introduced which undid much of the ecumenical work of the ICEL and also undermined co-operation. At the centre of this move was the issue of translation:

The initial translations were done according to the principle of 'dynamic equivalence' ... trying to capture the wider meaning of what is being said in the Latin more than on the words or style of the Latin itself. While no translation is ever perfect, the current wisdom of the Church is that a more literal rendering of the Latin is needed for a number of reasons. Therefore, this new translation is being done according to the principle of 'formal correspondence' - a more literal approach that tries to reflect the words and structures used in the original Latin more completely. (Agnoli 2009-2010:4)
The issue here is that there is a backward movement to restore the Latin Mass in all but the original tongue, although that too is now available. This is evidence of a counterecumenical perspective which is a denial of great advances made towards reconciliation with Protestants.

\section{A Protestant perspective}

A sound ecumenical Protestant view from the 1980s is offered by the Presbyterian theologian Robert McAfee Brown (1986):

.... what happens for the good in one branch of the Christian family redounds to the good of all, and just as clearly (maybe even more clearly), what is harmful to one is harmful to all. (p. 177)

From the beginning of John Paul II's pontificate, when considerable advances were made (e.g. in the Humanae dignitatus, ' $[t]$ he church in the world today', the Latin American bishops' documents from Medellin 1968 on justice and peace), 'Rome signalled a curial desire not only to bring such a new tendency under centralised supervision, but to neutralise them [liberation theology and base ecclesial communities] if possible' (McAfee Brown 1986:179). Whilst Protestants have appreciated John Paul II's comments on social, political and economic matters, much of the positive effect of this is nullified by 'constant reiteration of the primacy of Peter both substantially and ecclesiologically' (McAfee Brown 1986:179) as the pope constantly reiterates his views on papal primacy and authority derived from a medieval paradigm which is no longer appropriate (McAfee Brown 1986:181). 'I shall assume that there are no glaring differences between what the pope wills and what the curia does' (McAfee Brown 1986:181). Referring to the pope's first visit to the USA: 'He was carefully shielded from opinions that might have implied that truth can come from the bottom up as well as from the top down' (e.g. the case of Sister Theresa Kane) (McAfee Brown 1986:181). His visits were planned as media events rather than opportunities for listening and dialogue with a view to empowering his people locally to deal with their everyday problems (Collins 1986:55). From a Protestant viewpoint:

the greatest negative legacy of the present (John Paul II) pontificate will be its resolute shutting of all doors to women who wish to play a significant role in the life of the church. (McAfee Brown 1986:181)

McAfee Brown (1986) offered a number of important observations in his assessment of the post Vatican II period:

First, the freshness, excitement, and vitality of the catholic church are being sapped by the need to engage in so many diversionary struggles that are far from the main purpose of the gospel. ... Second, the atmosphere of domination from above puts a chill on reunion dreams from the Protestant side. No one has any illusions about the difficulty of realising Jesus' prayer 'that all may be one,' but during the pontificate of John XXIII, Protestants began to reassess the doctrine of authority and the modes of church government. ... But the image subsequent to Pope John XXIII is not so much an image of servanthood as an image of unilateral authority exercised from the top and resistant to challenge. ... third, ... God's purposes, whatever they may be, cannot be thwarted by men. (pp. 184-185)

All of this point to the fact that we live in an age of ecumenism despite taking one step forward and two steps backward at 
times. As outdated as McAfee Brown's comments were they are also disturbingly prophetic in terms of $\mathrm{RC}$ ecumenical orientation.

\section{We live in an age of ecumenism}

According to Wilde $(2007: 29,31)$ ' $[t]$ he key bone of contention was to what extent they [progressives] should prioritise rapprochement with the Protestants in order to engage the ecumenical movement'; for example, 'toning down Catholic devotion to Mary was an important goal for Catholic ecumenists.'

\section{The Blessed Virgin Mary}

The basic Marian dogmas, the Immaculate conception (1854) and the Assumption of Mary (1950), are regarded in Protestant circles as being without scriptural foundation.

Protestants view Mary as having been given a status parallel to Christ and/or the Holy Spirit:

\begin{abstract}
Bishops who wanted to improve ecumenical relations questioned the titles and accolades given to Mary in the schema and argued that Mary should not have her own schema but should instead be incorporated into a schema on the Church, because [...] 'it was not possible to speak of the Church without speaking of Mary'. (Wilde 2007:105)
\end{abstract}

We may compare this with John Paul II's strong devotion to the Marian cult (John Paul II 2005:165-171; Cornwell 2004:8489; Nowotny 1986:33; O'Connor 2005:19-29, 343-345). Yet, despite this, there was an existing and growing disposition towards greater co-operation with the church catholic and the world.

\section{Incipient ecumenism}

Ecumenism was already on the agenda of many Catholics, even by the time of Vatican II. Many bishops already had experience of fellowship and community engagement in situations where the element of competition was subsumed under a greater need to face common goals, interests and challenges (Wilde 2007:54). Following Vatican II, Küng (2003:277) in good faith stated ' $t$ ] he Catholic Church now has an ecumenical orientation. That can no longer be reversed. Or can it? That is what I ask myself after the event'. At that time, Catholics were talking about unity with Orthodox Christians. Protestants of many denominations were talking about getting together with Protestants of other denominations. And, of course, Catholics and Protestants were talking about collaborating on a variety of issues. Anglicans were even engaging with the idea of uniting with Catholics.

However, since the time Küng wrote those words, things have changed significantly. Benedict XVI in a speech at the University of Regensburg on 02 September 2006 entitled Faith, Reason and the University: Memories and Reflections, made questionable statements concerning the Reformation and about the Enlightenment as the de-Hellenisation of his own (Hellenistic-Roman) Christianity:
Dehellenization first emerges in connection with the postulates of the Reformation in the sixteenth century. Looking at the tradition of scholastic theology, the Reformers thought they were confronted with a faith system totally conditioned by philosophy, that is to say an articulation of the faith based on an alien system of thought. As a result, faith no longer appeared as a living historical Word but as one element of an overarching philosophical system. The principle of sola scriptura, on the other hand, sought faith in its pure, primordial form, as originally found in the biblical Word. (Benedict XVI 2006)

Then, on July 10, 2007, Pope Benedict issued a statement clarifying the Catholic Church's position on 'the church,' which again demanded a total identification of the church with the Roman Catholic Church as it currently is, contrary to the explicit desire of the Second Vatican Council. In Benedict's view, the Catholic Church is the only true church. Protestant communities, the pope said, 'cannot, according to Catholic doctrine, be called "Churches" in the proper sense,' because they lack apostolic succession, that is, the ability to trace their leadership back to Christ's original disciples. However, it raises the question whether or not apostolic succession is a mark of the church? This has to be seen in the light of a statement Benedict made in 2000 (quoted in Küng 2003:167) that the church does not need to be reformed, only its members. This implies that a sinful church cannot exist.

The reaction from non-Catholics was immediate: 'It makes us question whether we are indeed praying together for Christian unity', said the then World Alliance of Reformed Churches (WARC) (2007) (now the World Communion of Reformed Churches [WCRC]), a fellowship of 75 million Protestants in more than one hundred countries. The WCRC further states: 'It makes us question the seriousness with which the Roman Catholic Church takes its dialogues with the reformed family and other families of the church' (WARC 2007). According to the World Alliance (Cole 2007), Benedict's document took ecumenical dialogue back to the era before the Second Vatican Council, when many Protestants believed that Rome had changed its position and was more accepting of Protestant denominations and beliefs.

So what has the church taught 'down through the centuries'? Simply this, in the pope's own words:

Christ 'established here on earth' only one Church and instituted it as a 'visible and spiritual community', that from its beginning and throughout the centuries has always existed and will always exist, and in which alone are found all the elements that Christ himself instituted. This one Church of Christ, which we confess in the Creed as one, holy, catholic and apostolic ... This Church, constituted and organized in this world as a society, subsists in the Catholic Church, governed by the successor of Peter and the Bishops in communion with him. (Vatican n.d.)

Benedict did admit that Catholic doctrine admitted the possibility that the Church of Christ exists within other churches which are not at this stage in communion with Rome. However, he also affirmed that they possess defects, and therefore 'these venerable Christians lack something in their condition as particular churches' (Vatican n.d.). But, does the Catholic Church also not suffer from defects? And 
what do these others lack? The pope was unambiguous here too:

According to Catholic doctrine, these Communities do not enjoy apostolic succession in the sacrament of Orders, and are, therefore, deprived of a constitutive element of the Church. These ecclesial Communities which, specifically because of the absence of the sacramental priesthood, have not preserved the genuine and integral substance of the Eucharistic Mystery cannot, according to Catholic doctrine, be called 'Churches' in the proper sense. (Vatican n.d.)

Hebblethwaite (1975:234) quotes Bishop Butler ('Theology and life in community' in One in Christ, 1974, no.3:225) in this regard: 'Doctrinal agreement will only come when communion has been established.' He operates from the assumption that Christians already share the faith; they only differ in the manner in which that faith is formulated - a rather contrary view to that of the Vatican. Rome claims for itself, as a church, the authority which belongs only to Christ. For Protestants, it is not in the church but in Christ that we find 'the fullness of the means of salvation'. For Protestants, it is not the church but in Christ that we find forgiveness. For Protestants, not the church but Christ, 'is necessary for salvation'. Whilst Rome claims that all these come to the faithful by Christ, as Protestants teach, the difference is that for Rome, these are mediated to the faithful solely through the church, a teaching that is problematic to Protestants (Goldstein 2007).

Those from the Reforming tradition also have a theology of the church. They believe it is founded on Jesus Himself, the Rock (Mt 16:18), and which He invested with authority and power (Mt 18:17, 18), which was called to be 'the pillar and ground of the truth' (1 Tm 3:15). The biblical view is that the church is a group of those called out by Christ, who fellowship and worship together, who minister to each other together, and who witness to the world together of Jesus and his sacrifice. Indeed, it is through the church that God's reality is manifested 'in order that now, through the church, the wisdom of God in its infinite variety might be made known to the rulers and authorities in the heavenly realms' (Eph 3:10) (Goldstein 2007). The text had also explicitly declared 'communities emerging from the Reformation' - the Protestant and Anglican churches - are 'not Churches in the proper sense of the word' but rather 'ecclesial communities'.

In response, Setri Nyomi (General Secretary, WCRC [WARC]) challenged the authority of the Vatican to decide who is and is not called to be part of the church of Jesus Christ, saying that this is a gift of God. The WARC head further wrote: 'Receiving this gift, we appreciate the Roman Catholic Church as a part of this family.' The WARC head speaking for his organisation said it hopes the Roman Catholic Church moves beyond 'exclusivist claims' in order to further the cause of Christian unity (Cole 2007).

What is interesting is that everyone tends to claim that they are following the ethos and spirit of Vatican II and even though that understanding has become fluid through interpretation and re-interpretation through the years (see below 'the real untold story'). The Protestant understanding has tended to be more static relying on the texts of the original documents rather than the subsequent $\mathrm{RC}$ interpretations which are bound by tradition to remain faithful to earlier formulated dogmas such as those promulgated at Vatican I and earlier. Referring to John Paul II and Cardinal Ratzinger, Küng (1986:66-67) rather depressingly described the situation when Ratzinger's Report on the Faith (1985) was published prior to the Episcopal synod called to evaluate progress since Vatican II:

... the conciliar movement must be stopped; church reform
should be stopped; ecumenical understanding with the Eastern
Churches, Protestants, and Anglicans must be blocked; and
dialogue with the modern world must again play second fiddle
to unilateral teaching. ... what they have in mind is not the
progressive spirit of the Council [Vatican II] but rather the 'true
Council', the one that simply stands in continuity with the past
and did not signal a new beginning. (n.d)

The Report on the Faith prepared in preparation for the Episcopal synod (1985), demonstrated the negativity of the bishops to any denial of the gains of Vatican II. Ratzinger feared 'nothing more than freedom' (Küng 1986:59):

There is very little talk about faith, but a great deal about the institutional church, about dogmas and doctrines, and above all about 'un-Catholic' deviants in the episcopacy and amongst theologians. (Küng 1986:59)

Reformers and Vatican II appear to be clear that the nature of the church is a communion - "primarily as consisting of relationships' (Weakland 2003:8) - with God, with Jesus in the Spirit amongst the baptised and with the members of society, that is the church was accepted as 'imperfect and in need of constant conversion' (Weakland 2003:88). 'As long as it is in via ... the Church must constantly admit its own need of reform' (Weakland 2003:90).

Küng (1986) was extremely critical of the Report:

- The Protestant Reformation is written off in theological superficiality (p. 62).

- The Middle Ages are variously presented as exemplary (p. 63).

- Every modern interpretation of problematic church doctrines is rejected (p. 63).

- According to Cardinal Ratzinger, Vatican II hardly produced anything good (p. 63).

- $\quad$ Q]uestions of ecumenical understanding ... never got beyond the tediously familiar: nothing on the already existing unity documents, nothing on the recognition of Anglican orders and Protestant ordination, nothing on the recognition of the Eucharistic liturgy of other churches and on a possible shared Eucharist (p. 7).

But it is not all bad news for:

Fortunately, although the conciliar and ecumenical movement is constantly being obstructed and frustrated from above, it continues at the grassroots, in individual congregations. The result is increasing alienation of the 'church from below' from the 'church from above' to the point of indifference. (Küng 1986:71). 
... in many places the pastor and the faithful do whatever seems proper to them in matters like sexuality and marriage morality, mixed marriage and divorce, ecumenical collaboration and social commitment. They act in the spirit of the gospel and according to the impulses of Vatican II, unconcerned with the headwinds in the upper regions of the hierarchy. (Küng 1986:11)

And then, Küng (1986:62), not for the first time, challenges the Reforming tradition: 'I wonder whether Protestants will now take up the protest themselves again, instead of leaving it to critical Catholics.' This is a fair point, one which I alluded to at the beginning of this article regarding the Roman Catholic Church producing its own critics. But the matter of internal strife in the RC communion is a matter which needs some elucidation.

\section{'The real untold story'}

This sub-heading (Magister 2005a, b) refers to the strong divergence of opinion which has arisen within the Roman Catholic Church since Vatican II. This has been alluded to above but needs further explication. Since Vatican II, there has been a growing 'gap between Catholic Church historians (and historians of the councils in particular) and theologians, magisterium, and 'secular historians' on the other side' (Faggioli 2012:4-5). On one side was the 'Bologna School'. This approach was encapsulated in Alberigo and Komonchak's (1996-2005) The history of Vatican II. It focussed on the council as an event: 'The real council is the spirit of the council' (Magister 2005a, b). It was more than 'the words of its actual texts - the dogmas, laws, structures and traditions reading of the facts' (Magister 2005a). It was 'a "pastoral" Council with the purpose of bringing the bible and the modern world closer together' (Brandmüller 2005). This represented a decisive break with the past. Alberigo's hermeneutical criteria included: the council-event as a canon of interpretation; the intention of John XXIII; the 'pastoral' nature of the council; aggiornamento as the goal and the importance of compromise in interpreting the documents of the council (Faggioli 2012:13-14). Another criterion is that of ressourcement (O'Malley 2006:14-16) (adoption of the ad fontes principle of going to the source in the Earliest Christian community). It is interesting that there is no trace of a suggestion that this work was intended to detract from the faith of the Catholic Church (O'Malley 2006:6). The overarching aim was reconciliation but this constituted a grave threat to the conservatives in the church.

The opposing view presented a 'counterpoint' or 'polar opposite' to the Bologna School which depends to a large extent on conflicting narratives, producing a crisis of historical awareness, which are susceptible to 'ideological manipulation' (Faggioli 2012:18). This was promoted by Cardinals Agostino Marchetto and Camillo Ruini (in continuity with John Paul II and Benedict XVI) who challenged the view of Vatican II as a break with the past, despite Archbishop Lefèbre's view of the council as heretical and which resulted in schism. They based their argument on continuity with tradition and with biblical and patristic foundations (Faggiloi 2012:10). O’Malley (2006) quotes John Paul II in this regard:
The church has always known the rules for a correct interpretation of the contents of dogma. These rules are woven into the fabric of faith and not outside it. To read the council as if it marked a break with the past, while in fact it placed itself in the line of the faith of all times, is decidedly unacceptable. (p. 5)

Ruini (in Magister 2005a, b), in support, summarised his position as:

The interpretation of the council as a rupture and a new beginning is coming to an end. This interpretation is very feeble today, and has no real foothold within the body of the Church. It is time for historiography to produce a new reconstruction of Vatican II which will also be, finally, a true story. (n.p.)

He adopted this position apparently unconscious of, or in opposition to, the dynamic nature of the tradition in which he stood. Yet, it is apparent that the after-effects of Vatican II are part of a dynamic process in terms of both 'letter' and 'spirit'. Whatever view is adopted, through the transmission of memory, global Catholicism is a dynamic factor in a rapidly changing world. In sum, 'Vatican II was a celebration of the perennial faith of the Catholic Church' (O'Malley 2006:7).

\section{Conclusion}

Wilde's (2007) optimistic evaluation of Vatican II was somewhat wide of the mark despite its laudable intention:

... the Roman Catholic Church relinquished its claim to be the one true church, and with it, abdicated claims to power in relation to nation states, by declaring that the only just form of government was one under which people were free to worship as they pleased. ... Most importantly, Vatican II changed the way the Church understood itself, as its identity went from being a hierarchical authority to a church conceived of as the people of God. ... Perhaps the most well-known cultural change that resulted from the Council was the shift in the Church's identity from a 'hierarchical teaching authority' to 'the people of God' with countless implications for the church's doctrine, ritual and practices. Along with transforming the Church's culture, Vatican II, at least temporarily, profoundly altered the modes of power, and within them, the distribution of key resources within the Church. (p. 15)

However, she does admit:

while some hierarchies took the reforms of the Council home and applied them in very radical ways, the Church, particularly the Vatican, has also gone in a very conservative direction since the Council ... (Wilde 2007:127)

For Protestants, these comments summarise the dilemma. Vatican II helped them onto a new threshold of understanding along with a desire for closer relationships. It marked a paradigm shift which brought all to the brink of a new ecumenical era. A substantial part of this transformation has its source in the documents of the council which demonstrated a new and innovative theological disposition. These were substantially the work of a younger generation of theologians doing battle with the Curia who found them to be a serious threat to their power and authority. The saddest thing is that, in Protestant eyes, the hierarchy has relegated itself to the status of a backwater community as happened to the early church in Jerusalem under the leadership of conservative Jewish Christians. Despite continuing attempts 
at ecumenical engagement, with a Roman Catholic Church which is sadly divided amongst itself, the outlook looks bleak at an institutional level. Our ecumenical hope has to be invested in promoting initiatives at local level where all new authentic growth is normally to be found. It was as a direct result of Vatican II that Protestants rediscovered their calling to be reforming Catholics.

\section{Acknowledgement Competing interest}

The author declares that he has no financial or personal relationship(s) which may have inappropriately influenced him in writing this article.

\section{References}

Abbott, W.M. (ed.), 1966, The Documents of Vatican II, Geoffrey Chapman, London. Agnoli, F.I., 2009-2010, 'Introducing the third edition of the Roman missal', in The Catholic Messenger, viewed 15 December 2012, from http://www. davenportdiocese.org/lit/liturgylibrary/ litONewMissalSeriesCombined.pdf

Alberigo, G. \& Komonchak, J.A., 1996-2005, The history of Vatican II, 5 vols., Orbis, Maryknoll.

Benedict XVI, 2006, 'Faith, reason and the university: Memories and reflections', in Zenit: The world seen from Rome, viewed 08 September 2012, from www.zenit. org/article-16955? |=english

Bevans, S., 2010, 'From Roman Catholic church to world church: Roman Catholic theological education', in D. Werner, D. Esterline, N. Kank \& R. Raja (eds.),
Handbook of theological education in world Christianity: Theological perspectives, Handbook of theological education in world Christianity: Theological pers
ecumenical trends, regional surveys, pp. 3-12, Cluster, Pietermaritzburg.

Brandmüller, W., 2005, 'Vatican II in the history of councils', in Avenire, viewed 25 February 2013, from http://chiesa.espresso.repubblica.it/articolo/43223?eng=y

Busch, E., 2010, The Barmen theses: Then and now, Eerdmans, Grand Rapids.

Chadwick, O, 1993, The Christian church in the Cold War, Penguin, London.

Chaves, M., 2011, American religion: Contemporary trends, Princeton University Press, Princeton.

Cole, E., 2007, 'Reformed church head rebuts Vatican's "One true church" claim', Christian Post Reporter, 11 July, n.p.

Collins, P., 1986, 'The peripatetic pope: A new centralising of power', in H. Küng \& L. Swidler (eds.), The church in anguish: Has the Vatican betrayed Vatican II?, pp. 52-57, Harper \& Row, San Francisco.

Conway, M., 2010, 'Issues for theological education in the $21^{\text {st }}$ century', in D. Werner D. Esterline, N. Kank \& R. Raja (eds.), Handbook of theological education in world Christianity: Theological perspectives, ecumenical trends, regional surveys, pp. 23-29, Cluster, Pietermaritzburg.

Cornwell, J., 2004, The pope in winter: The dark face of John Paul's legacy, Penguin, London.

Costigan, R.F., 2005, The consensus of the church and papal infallibility, The Catholic University of America Press, Washington. PMCid:1550640

Duffy, E., 2003, 'Tradition and reaction: Historical resources for a contemporary renewal', in A. Ivereigh (ed.), Unfinished journey: The church 40 years after Vatican II, pp. 49-68, Continuum, New York.

Dulles, A., 1971, The survival of dogma, Doubleday, New York.

Edwards, D.L., 1997, Christianity: The first two thousand years, Cassell, London.

Faggioli, M., 2012, 'Vatican II: The history and the narratives', Theological Studies 73, 1-19.

Goldstein, C., 2007, 'Benedict's surprise', in Signs of the Times, viewed n.d, from http://www.signstimes.com/?p=article \&a $=44107140289.692$

Gonzales, J.L., 1975, A history of Christian thought: From the Protestant Reformation to the twentieth century, Abingdon, Nashville.

Greeley, A.M., 1986, 'The lay reaction', in H. Küng \& L. Swidler (eds.), The church in anguish: Has the Vatican betrayed Vatican II?, pp. 284-288. Harper \& Row, San Francisco.

Hastings, A. (ed.), 1999, A world history of Christianity, Cassell, London.

Hebblethwaite, P., 1975, The runaway church, Collins, London.

Hebblethwaite, P., 1980, The new inquisition? Schillebeeckx and Küng, Fount, London.

Higton, M., 2004, Difficult gospel: The theology of Rowan Williams, SCM, London. PMid:15295817

Ivereigh, A. (ed.), 2003, Unfinished journey: The church 40 years after Vatican II, Continuum, New York.

John Paul II, 2005, Memory and identity: Personal reflections, Wiedenfield \& Nicolson, London. PMCid: 1151857

Kennedy, E.C., 1986, 'The problem that has no name', in H. Küng \& L. Swidler (eds.), The church in anguish: Has the Vatican betrayed Vatican II?, pp. 300-305, Harpe \& Row, San Francisco.

Küng, H., 1971a, Infallible? Collins, London.
Küng, H., 1971b, The Church, Search Press, London.

Küng, H., 1978, On being a Christian, Collins, Glasgow.

Küng, H., 1986, 'Cardinal Ratzinger, Pope Wotjtyla, and fear at the Vatican: An open word after a long silence', in H. Küng \& L. Swidler (eds.), The church in anguish: Has the Vatican betrayed Vatican II?, pp. 58-74, Harper \& Row, San Francisco.

Küng, H., 2001, The Catholic church, Phoenix, London.

Küng, H., 2003, My struggle for freedom: Memoirs, Continuum, London.

Küng, H., 2008, Disputed truth: Memoirs II, Continuum, London.

Küng, H., 2010, What I believe, Continuum, London.

Küng, H. \& Swidler, L. (eds.), 1986, The church in anguish: Has the Vatican betrayed Vatican II? Harper \& Row, San Francisco.

Lash, N., 2003, 'Vatican II: Of happy memory - and hope?', in A. Ivereigh (ed.), Unfinished journey: The church 40 years after Vatican II, pp. 234-250, Continuum, New York.

Lennan, R., 2010, 'Roman Catholic ecclesiology', in G. Mannion \& L.S. Mudge (eds.), The Routledge companion to the Christian Church, pp. 234-250, Routledge, London.

Lohse, B., 1985, A short history of Christian doctrine: From the first century to the present, Fortress, Philadelphia.

Lonergan, B., 1967, 'The transition from a classicist world view to historical mindedness', in J.E. Biechler (ed.), Law for liberty: The role of law in the church today, n.p., Helicon Press, Baltimore.

Magister, S., 2005a, 'Benedict XVI is to reinterpret the Second Vatican Council. This is the preface', in www.chiesa.expressonline.it, viewed 25 February 2013, from http://chiesa.espresso.repubblica.it/articolo/43223?eng $=y$

Magister, S., 2005b, 'Vatican II: The real untold story', in www.chiesa.expressonline. it, viewed 25 February 2013, from http://chiesa.espresso.repubblica.it/ articolo/43223?eng=y

Marty, M., 2007, The Christian world: A global history, Random House, New York.

Massa, M.S., 2010, The American Catholic revolution: How the 60s changed the church forever, Oxford University Press, Oxford. http://dx.doi.org/10.1093/acprof :oso/9780199734122.001.0001

Mayflower Statement, 1968, New York Times, 31 July, p. 16.

McAfee Brown, R., 1986, 'A Protestant look at an aggressive papacy', in H. Küng\& L. Swidler (eds.), The church in anguish: Has the Vatican betrayed Vatican II?, pp. 177-185, Harper \& Row, San Francisco.

McBrien, R.P., 1986, 'Theology in Catholic higher education', in H. Küng \& L. Swidler (eds.), The church in anguish: Has the Vatican betrayed Vatican II?, pp. 295-299, Harper \& Row, San Francisco.

McNeill, J.T., 1969, 'Protestantism', in A. Richardson (ed.), A dictionary of Christian theology, SCM, London, p. 279.

Modras, 1986, 'A man of contradictions? The Early writings of Karol Wojtyla', in H. Küng \& L. Swidler (eds.), The church in anquish: Has the Vatican betrayed Vatican II?, pp. 39-51, Harper \& Row, San Francisco.

Novak, M., 2003, 'The "open church" 40 years later: A reckoning ', in A. Ivereigh (ed.), Unfinished journey: The church 40 years after Vatican II, pp. 32-48, Continuum, New York.

Nowotny, A., 1986, 'Fortress Catholicism: Wojtyola's Polish roots', in H. Küng \& L. Swidler (eds.), The church in anguish: Has the Vatican betrayed Vatican II?, pp. 21-38, Harper \& Row, San Francisco.

O'Connor, G., 2005, Universal father: A life of John Paul II, Bloomsbury, London.

O'Malley, J.W., 2006, 'Vatican II: Did anything happen?', Theological Studies 67, 3-33.

Pawley, B., 1962, Looking at the Vatican Council, SCM, London.

Radcliffe, T., 2003, 'Power and powerlessness in the church: The chance of renewal', in A. Ivereigh (ed.), Unfinished journey: The church 40 years after Vatican II, pp. 119-134, Continuum, New York.

Ratzinger J., 1985, The Ratzinger Report: An exclusive interview on the State of the Church, Ignatius Press, San Francisco.

Revised Church Hymnary, 1927, The church hymnary, rev. edn., Oxford University Press, London.

Richardson, A. (ed.), 1969, A dictionary of Christian theology, SCM, London.

Schloesser, S., 2006, 'Against forgetting: Memory, history, Vatican II', Theological Studies 67, 275-319.

Swidler, L., 1986, 'Democracy, dissent and dialogue: A Catholic vocation', in H. Küng, \& L. Swidler (eds.), The church in anguish: Has the Vatican betrayed Vatican II?, pp. 289-294, Harper \& Row, San Francisco.

Tracy, D., 1986, 'On hope as a theological virtue in American Catholic theology', in H. Küng \& L. Swidler (eds.), The church in anguish: Has the Vatican betrayed Vatican II?, pp. 268-272, Harper \& Row, San Francisco.

Vatican, n.d., Francis, viewed 24 May 2012, from http://www.vatican.va/phome_en.htm

Weakland, R., 2003, 'Images of the church: From "perfect society" to 'God's people on pilgrimage', in A. Ivereigh (ed.), Unfinished Journe: The Church 40 years after on pilgrimage', in A. Ivereigh (ed.), Unfinished
Vactican II, pp. 78-90, Continumm, New York.

Wilde, M.J., 2007, Vatican II: A sociological analysis of religious change, Princeton University Press, Princeton.

World Alliance of Reformed Churches (WARC), 2007, Newssytem Accra 2004, viewed 24 May 2012, from http://warc.jalb.de/warcajsp/side.jsp?news_id=1209\&part id $=0$ \& navi $=6$

Woodrow, A., 1995, 'Free speech in the Church', The Tablet, August, 1093-1095.

Woodrow, A., 2003, 'The church and the media: Beyond Inter mirifica', in A. Ivereigh (ed.), Unfinished journey: The church 40 years after Vatican II, pp. 208-226, Continuum, New York. 